Ann. Zootech., I970, 19 (4), 473-526.

\title{
ÉCONOMIE
}

\section{LA MULTINATIONALISATION DE L'ÉConomie PORCINE}

\author{
J. LE BIHAN \\ Laboratoire de Recherches sur l'Économie des Industries alimentaires, \\ C. E. R. D. I. A., \\ $91-$ Massy \\ Institut national de la Recherche agronomique
}

\section{RÉSUMÉ́}

La multinationalisation des entreprises est l'une des caractéristiques dominantes des économies développées. Cette tendance progresse rapidement dans l'ensemble agro-alimentaire. L'économie porcine n'échappe pas à cette tendance générale. On examinera les facteurs de multinationalisation, les modalités et l'ampleur du phénomène.

Enfin, on présentera quelques hypothèses d'évolution.

\section{SUMMARY}

\section{INTERNATIONALISATION OF THE PIG INDUSTRY}

The internationalisation of corporations is one of the main characteristics of high developed firms. It progresses rapidely in the whole agribusiness sector and the new pig industry is also affected by this general trend. The factors of internationalisation, the modalities and the importance of the phenomenon will be examined.

Finally, we discuss some hypothesis of development. 